\title{
The Implementation of Pregnant Mother Class Program in Aceh Barat District
}

\author{
Teungku Nih Farisni ${ }^{1}$, Yarmaliza $^{2}$, Fitriani ${ }^{3}$ \\ ${ }^{1,2,3}$ Faculty Of Public Health, Teuku Umar University, Indonesia. \\ Email Coreponding Author: teungkunihfarisni@utu.ac.id
}

\begin{abstract}
The total of pregnant women in Aceh Barat District in 2018 is 44530 people. The total of deaths was 3 and than the total of infant deaths was 90 . The importance of pregnant mothers class programs as an effort to reduce maternal mortality and infant mortality rates. The purpose of this study was to analyze the study of Communication, Resources, Disposition, and Bureaucratic Structure in the Implementation of the Mother Class Program in West Aceh District. This type of research is descriptive qualitative research that is the method used to explore or analyze a study but is not used to make broader conclusions. The sampling technique used purposive sampling with 16 main informants, 1 key informant and 1 supporting informant. Data collection techniques with in-depth interviews. Data analysis uses content analysis. The results of research on communication studies are still not good, resources are incomplete. Disposition is still lacking in commitment, and bureaucratic structure is still lacking in cooperation. The implementation of the Pregnant Women Class Program in West Aceh district is still inappropriate and there are still many obstacles and obstacles. The conclusion is that there is still a lack of communication across sectors, the lack of resources to carry out maximum implementation, the lack of commitment from decision makers, and the bureaucratic structure is still lacking of cooperation so that the implementation of the pregnant mothers class program cannot run properly and optimally. Suggestions are expected to build good communication across sectors, decision makers seek to maximize available resources in the implementation of classes for pregnant women, build cooperation in bureaucratic structures and for pregnant women are expected to continue to follow the Pregnant Women Class routinely and to the end so that pregnant women class programs can run effectively.
\end{abstract}

\section{Keywords: Implementation, Class of Pregnant Women, Communication, and Resources}

\section{Introduction:}

One of the efforts in supporting health in Indonesia is prioritizing efforts to improve the health status of mothers and children, especially in the most vulnerable groups of health, such as pregnant women, childbirth, childbirth and newborns (Kemenkes RI, 2011). In Indonesia the maternal mortality rate in 2015 was better than in 2014. This was indicated by the decrease in maternal mortality rate, if in 2014 it was 104.7 / 100,000 Live Births which were 14 cases, whereas in 2015 there were 11 cases by $87.5 / 100,000$. AKI's 2015 target is $70 / 100,000$ Live Births. Child health efforts are expected to reduce child mortality. Indicators of child-related 
mortality are Neonatal Mortality Rate (AKN), Infant Mortality Rate (IMR), and Toddler Mortality Rate (AKABA). Attention to efforts to reduce neonatal mortality (0-28 days) is important because neonatal mortality contributes to $59 \%$ of infant deaths (Ministry of Health Republic of Indonesia, 2015).

In Aceh Province, the proportion of maternal deaths is still dominated by postpartum maternal deaths, which is 70 mothers or $52 \%$, followed by maternal deaths as many as 34 mothers or $25 \%$ and maternal deaths as many as 30 mothers or $23 \%$. AKI calculation in each district / city is difficult, because the number of live births does not reach 100,000 births and there is still the possibility of underreporting. An effective effort to reduce maternal mortality is to increase delivery assistance by health professionals in health facilities, as well as increase the use of postpartum contraception and management of maternal complications. (Aceh Health Office, 2015).

In West Aceh Regency the number of pregnant women in 2018 is 44530 people. The number of maternal deaths in 2018 is as many as 5 people and the number of infant deaths in 2018 is as many as 90 babies. (West Aceh Health Office, 2018).

Pregnant Women Class is a study group of pregnant women with gestational age between 20 weeks to 36 weeks (before delivery) with a maximum number of participants of 10 people. Pregnant women will learn together in this class, they are trained to discuss and exchange experiences on maternal and child health $(\mathrm{MCH})$ thoroughly and systematically and can be carried out in a scheduled and continuous manner. Classes of pregnant women are facilitated by midwives or health workers by using a package of classes for pregnant women, namely the $\mathrm{MCH}$ book, flip chart (turning sheet) (Ministry of Health Republic of Indonesia, 2011).

Pregnant mothers class is expected to increase knowledge, change the attitude and behavior of mothers to understand about pregnancy, body changes and complaints during pregnancy, pregnancy care, childbirth, postpartum care, postnatal family planning, infectious diseases and birth certificates (Ministry of Health Republic of Indonesia, 2011).

Implementing classes of pregnant women are generally midwives. Midwives in this case have the task as facilitators in the pregnant mothers class program, which in carrying out classes of pregnant women who can ask for help from resource persons to deliver material in certain fields (Kemenkes RI, 2011). 
Based on a preliminary survey conducted with 10 Pregnant Women in West Aceh District where 8 of them said that they did not get information or information from Midwives or Health Officers who carried out the program prior to the implementation of the Pregnant Mothers Class Program and there were still pregnant women who did not know of any class programs pregnant mother.

Based on the observations carried out in two posyandu, the lack of facilities and infrastructure is still lacking, such as a study room that is too small, so the process of providing maternal class material is not effective. Results of Interviews with Midwives or Health Officers who run the Pregnant Class Program The attitude of executors in carrying out tasks such as lack of commitment in carrying out the Pregnant Class Program and the lack of form of coordination and cooperation with community leaders and parties concerned so that socialization is still not going well.

\section{Method}

This type of research is descriptive qualitative research that is the method used to explore or analyze a study but not used to make broader conclusions (Sugiyono, 2012). The aim is to find out and describe the implementation of the Pregnant Mothers Class Program in West Aceh District. This research was conducted from January 22 to July 11, 2018 in the District of West Aceh. The sampling technique used in this study was purposive sampling by fulfilling the inclusion and exclusion criteria with 16 main informants consisting of 13 coordinating midwives and 3 pregnant women, 1 key informant namely the head of the health department. Data collection techniques with in-depth interviews. Data analysis uses content analysis.

Inclusion criteria:

1. Willing to be an informant

2. Holder of the pregnant mothers class program

3. Pregnant women who are actively carrying out classes of pregnant women

Exclusion Criteria:

1. Not willing to be an informant

2. Not a holder of a pregnant mothers class program

3. Pregnant women who do not actively carry out classes of pregnant women 


\section{Result}

Based on research that has been done, regarding the Implementation of Pregnant Classes Program in West Aceh District, the results of researchers' interviews with Pregnant Women, Village Midwives, Coordinating Midwives, and the Head of Puskesmas, in general the Implementation of Pregnant Classes Program is still less appropriate and there are still many obstacles and obstacles .

The results of research conducted by researchers with 16 main informants (13 coordinating midwives and 3 pregnant women), 1 key informant (Head of health department) of 4 Variables namely Communication, Resources, Disposition and Bureaucratic Structure, showed that the implementation of Class of Pregnant women has not been socialized so well that not all target groups, which in this case are pregnant women, understand the benefits, goals and existence of the mother's class.

Then also from the attitude or commitment of the implementation of the Class Program for Pregnant Women such as village midwives has not been good, as evidenced from the inactivity of village midwives in conducting socialization of the mother class. Then also facilities and infrastructure that are not complete so that the class of pregnant women cannot be carried out to the maximum and also the class of mothers is still not in accordance with the guidelines of the class of pregnant women, so that the class program of pregnant women themselves is ineffective.

\section{Communication}

Based on the results of research Communication is important in the Implementation of Pregnant Women Class Program because Communication is the process of delivering good, clear and consistent information. The results of the research that have been conducted show that communication between village midwives and pregnant women is still poor, such as village midwives who do not provide information or information prior to the implementation of the pregnant mothers class program, so that there are still many mothers who do not attend maternal classes and even pregnant mothers who rarely come to posyandu.

Communication in the Implementation of the Pregnant Class Program can be measured by several indicators, namely 1. Transmission, 2. Clarity, 3. Consistency. Policy information needs to be conveyed to policy actors so that policy actors can know, understand what the contents, objectives, directions and target groups of the policy are so that policy actors can 
prepare properly what needs to be prepared and carried out to implement public policies so that what are the goals and objectives of the policy can be achieved in accordance with that applied. (Widodo in Sahara 2016). In line with research (Latif 2013) it has not been sufficiently well socialized in the efforts to establish, assist and revitalize the class of mothers.

\section{The Resource}

Based on the results of research Resources Resource factors have an important role in policy implementation, because if those who implement the program and those responsible for implementing the program lack the resources to carry out work effectively, then the policy implementation will not be effective. The sources in question are: Staff, Information, Authority and Facilities. The results of research that have been done show that the resources to implement the Pregnant Women Class Program are still incomplete such as, blackboards, CD for pregnancy exercises. Then there are posyandus that do not have their own buildings, such as in the village of Seumuleng holding posyandus and pregnant mothers classes in village halls and layung villages implementing posyandu and pregnant women classes in early childhood education.

Resources is where even though the contents of the policy have been clearly and consistently communicated, if the implementor lacks the resources to implement, then the implementation will not be effective. These resources can be in the form of human resources, for example the competence of the implementor and financial resources. (Edward in Nurdin 2013). In line with research (Purwandani 2013) Judging from the infrastructure of classes of pregnant women $100 \%$ is incomplete. Facilities and infrastructure needed for the class of pregnant women are the study room, writing instruments, the Maternal Child Health book, the flipchart for the class of pregnant women, the manual for implementing the class of pregnant women, the facilitator's handbook, props, mats / carpets, pillows, chairs, pregnancy exercise books and / or pregnancy exercise CD.

\section{The Disposition}

Based on the results of the research Disposition can be interpreted as the attitude of the implementers to implement a program. in the implementation of the program, if they want to succeed effectively and efficiently the implementers only know what needs to be done and have 
the ability to carry out the program, but they also must have commitment and consistency in implementing the program.

The results of the research that have been done show that the attitude or commitment of the Pregnant Class Program implementers such as village midwives has not been good, for example village midwives who are still lacking in providing information about special posyandu classes for pregnant women so that not all pregnant women know what a pregnant mothers class program is.

Disposition, is the character and characteristics possessed by the implementor. If the implementor has a good disposition, then the implementor can run the policy as well as what is desired by the policy maker. (Edward in Haerul 2014). In line with research (Nurdiyan 2015) the lack of activeness of pregnant mothers class managers from districts and community health centers.

\section{The Bureaucratic Structure}

Based on the research results Bureaucratic structure is a form of coordination and cooperation between the parties involved in implementing a program. The results of the research that have been carried out show that the lack of cooperation with related parties, as well as from the Puskesmas itself still lacks support for the Proram class of pregnant women themselves. And from the Health Office itself, there is also a lack of commitment in implementing the pregnant mothers class program, as evidenced by the results of interviews and observations from four research villages, all of these villages do not have complete facilities and infrastructure for pregnant mothers class programs.

Bureaucratic structure, is the composition of work units within the organization that shows the division of labor and the clarity of how different functions or activities are integrated or coordinated, in addition to that the organizational structure also shows the specialization of work, command channels and report submission . (Edward in Haerul 2014) In line with research (Lia, 2012), there are no complete facilities provided by the Health Service, only given in the form of a package of 1 class pregnant women books, flipcharts, pamphlets. For facilities such as places is an agreement between pregnant women, cadres and midwives. In addition, other facilities such as carpets, stationery, chairs and contributions from pregnant women, cadres and midwives. 


\section{Conclusion}

Based on the results of the study, it can be concluded that:

1. Implementation of the results of the research that has been done shows that the implementation is still not good, lack of funds from the Health Office to complete the facilities and infrastructure for the implementation of the Pregnant Women Class, and the lack of commitment from midwives in village midwives who carry out the class of pregnant women so that the implementation does not run smoothly, and the inappropriate implementation of activities with the Guidelines for Pregnant Women Classes so that the Implementation of the Pregnant Women Class Program in the work area of the Layung Health Center does not run optimally and effectively.

2. Communication of the results of research that has been done shows that communication between village midwives and pregnant women is still poor, such as village midwives who do not provide information or information prior to the implementation of the pregnant mothers class program, so that there are still many women who do not attend the mother's class and even have pregnant women who rarely come to the posyandu.

3. The results of research conducted indicate that the resources to implement the Pregnant Women Class Program are still incomplete such as, blackboards, CD for pregnancy exercises. Then there are posyandus that do not have their own buildings, such as in the village of Seumuleng holding posyandus and pregnant mothers classes in village halls and layung villages implementing posyandu and pregnant women classes in early childhood education.

\section{Reference}

Agustino Leo. 2012. Dasar-Dasar Kebijakan Publik. Bandung; Alfabeta.

Dinas Kesehatan Aceh. 2015. Profil , 2012. Pedoman Pelaksanaan Kelas Ibu Hamil. Direktorat Jendral Bina Gizi dan

KIA. Jakarta

2014. Pedoman Pelaksanaan Kelas Ibu Hamil. Direktorat Jendral Bina Gizi dan KIA. Jakarta . 2014. Profil Kesehatan Indonesia 2013. Jakarta: Kementrian Kesehatan RI . 2015. Profil Kesehatan Indonesia 2014. Jakarta: Kementrian Kesehatan RI 
Kemkes RI, 2010. Kinerja Satu Tahun Kementrian Kesehatan Republik Indonesia tahun 2009 2010, Jakarta

Kemenkes, 2011. Lampiran Peraturan Menteri Kesehatan Nomor 2562/Menkes/Per/XII/2011 Tentang Petunjuk Teknis Jaminan Persalinan, Jakarta Kemenkes.

Latif, Vita Nur. 2013. Studi Implementasi Pendampingan Pembentukan dan Revitalisasi Kelas Ibu(Mother Class) di Kabupaten Pekalongan. Pekalongan : Universitas Pekalongan

Marenden, ebony. 2011. Implementasi Kebijakan Rehabilitasi dan Reklamasi Hutan di Kabupaten Mamuju. Makasar : Universitas Hasanuddin

Nurdin, Asrul. 2013. Implementasi Kebijakan Peraturan Daerah No 2 Tahun 2008 Tentang Pembinaan Anak Jalanan, Gelandagan, Pengemis, Dan Pengamen Di Kota Makassar. Makasar : Universitas Hasanuddin

Nurdiyan, Ayu. 2015. Analisis Sistem Pelaksanaan Kelas Ibu Hamil di Puskesmas Malalak dan Biaro Kabupaten Agam. Padang : Universitas Andalas Padang

Purwandani.W, Septerina. 2013. Evaluasi Proses Pelaksanaaan Kelas Ibu Hamil Di Kabupaten Banyumas. Semarang : DIII Kebidanan Purwokerto. Volume 2. No. 4. ISSN : 2089-7669

Puspitasari, Lia. 2012. Gambaran Pelaksanaan Kelas Ibu Hamil Di Puskesmas Bangetayu Kota Semarang. Semarang : Universitas Diponegoro. Volume 1. No. 2

Sahara, Suci. 2016. Analisis Implementasi Kebijakan Revitalisasi Posyandu di Wilayah Kerja Puskesmas Jeuram Kecamatan Seunagan Kabupaten Nagan Raya. Aceh Barat : Universitas Teuku Umar

Sugiyono. 2012. Metode Penelitian Kuantitatif Kualitatif dan R \& D. Bandung; Alfabeta Sunarto, 2004. Asuransi kesehatan Sosial. Web. www.cbn.com. Di Akses Agustus 2016. 
